\title{
Effectiveness of Learning Transportation Network Growth through Simulation
}

\author{
Wenling Chen ${ }^{1}$ and David M. Levinson ${ }^{2}$
}

\begin{abstract}
Computer simulation plays an increasingly important role in engineering education as a tool for enhancing classroom learning. This research investigates the efficacy of using simulation in teaching the topic of transportation network growth through an experiment conducted at the Civil Engineering Department of the University of Minnesota. In the experiment, a network growth simulator program $(S O N G)$ was incorporated into a senior/graduate class in transportation system analysis. Results of the experiment show that the use of $S O N G$ effectively enhanced students' learning in terms of helping students develop in-depth understanding about the development process of network patterns, and helped them develop some aspects of judgment, problem-solving, and decision-making skills. However, the use of $S O N G$ may have been more effective had some other barriers to learning been overcome.
\end{abstract}

DOI: 10.1061/(ASCE)1052-3928(2006)132:1(29)

CE Database subject headings: Simulation; Engineering education; Transportation networks.

\section{Introduction}

Conventional transportation engineering and planning education addresses the topic of travel demand modeling and network growth dynamics through lectures on general theories, pencil and paper problems, or class projects on related topics. Although this traditional approach imparts knowledge, there remains room to explore alternative teaching strategies to improve teaching outcomes by accommodating different learning styles, promoting active learning, and providing opportunities for students to practice judgment and problem-solving skills.

Simulation complements traditional engineering education methods. Simulations are engaging and allow learners to internalize knowledge by applying new skills in a risk-free environment, which can dramatically increase motivation and retention rates and provide a high return on learning efforts (Billhardt 2004). Despite its potential, simulations are used infrequently in transportation engineering and planning education. One major barrier that prevents wide adoption of simulation lies in the uncertainty over how to develop, use, and incorporate simulations successfully into existing education environment (Billhardt 2004).

To bridge the gap, a transportation network growth simulator is developed and incorporated into a senior/graduate level transportation system analysis course as an assignment. Based on the assignment, the writers designed an experiment which enables an

${ }^{1}$ MSN-902, 1818 H St. NW, Washington, DC 20433; formerly, Wilbur Smith Associates, 59 Middle St., Portland ME 04101. E-mail: wchen3@worldbank.org

${ }^{2}$ Dept. of Civil Engineering, Univ. of Minnesota, Twin Cities, 500 Pillsbury Dr. SE, Minneapolis, MN 55455 (corresponding author). E-mail: levin031@umn.edu

Note. Discussion open until June 1, 2006. Separate discussions must be submitted for individual papers. To extend the closing date by one month, a written request must be filed with the ASCE Managing Editor. The manuscript for this paper was submitted for review and possible publication on September 28, 2004; approved on February 1, 2005. This paper is part of the Journal of Professional Issues in Engineering Education and Practice, Vol. 132, No. 1, January 1, 2006. CASCE, ISSN 1052-3928/2006/1-29-41/\$25.00. efficacy test on the network growth simulator as used in this class. This paper documents the process of the experiment and reports the findings from the evaluation.

\section{Simulation in Education}

Advanced education and teaching are increasingly based on technological innovations in the area of multimedia and computerbased instruction (Alavi et al. 1997). One of these innovations is the application of simulation. By definition, simulation is a dynamic representation of some part of the real world by building a computer model and moving it through time (Drew 1968). Simulation allows learners to engage actively by running experiments, testing different strategies, and building a better understanding of the aspects of the real world which the simulator depicts (Pursula 1999). In simulation, learners' individual choices lead them down different paths toward different outcomes. Essentially, simulation lets students learn directly from the outcomes of their own actions (Senge 1990; Aldrich 2003; Billhardt 2004). In particular, the value of simulation in transportation education can be summarized as the following.

\section{Simulation Provides Learners with Experiences}

The importance of experience in human learning has long been emphasized. Phenomenological studies of human learning indicate that people pass through several levels in the learning of skills, ranging from the technical to the intellectual. High-level performance within a given area requires expertise based on experience, intuition, and judgment (Dreyfus and Dreyfus 1986; Flyvbjerg 2001). Conventional approaches to transportation education emphasize rationality and are dominated by analytical training, which tend to deemphasize sensitivity to experience, context, and intuition (Flyvbjerg 2001). One reason for less emphasis on experiential learning lies in the fact that real world experience in transportation is difficult to apply to classroom 
learning because effects of transportation policies take decades to materialize; additionally, the risks and costs of experimenting with transportation policies and concepts in the real world are prohibitively high. Simulations compress time and space. Through simulation, experiential learning can be facilitated and encouraged.

\section{Simulation Provides Opportunities for "Learning through Doing"}

Many people learn best through taking actions, or "learning by doing" (Dreyfus and Dreyfus 1986; McKeachie 1986; Senge 1990; Lowman 2001; Lerman 2002). Rationales for learning by doing are rooted from the constructivist learning theories of Piaget (1955), according to whom, knowledge is constructed, discovered, transformed, and extended by learners; the role of faculty is to create conditions to facilitate knowledge construction by students (Johnson et al. 1998; Lowman 2001). Simulation creates an environment to engage students in experiments and knowledge construction (Resnick 1997).

\section{Simulation Provides Interactive Learning Environment}

Many students also learn from experience, but this learning only occurs if the consequences of actions and decisions are experienced in a rapid and unambiguous manner (Senge 1990; Billhardt 2004). Providing quick feedback in an interactive manner is one of the advantages of simulators compared to other tools of experiential learning such as case studies, which, while allowing students to experience decision-making, are less effective in providing feedback. In simulation, feedback can be given right after an action is taken, in which way learners tend to be more open to internalizing knowledge (Billhardt 2004).

\section{Simulation Diversifies Teaching Strategies}

Diversifying teaching methods helps learning because it is a way to accommodate students' different learning styles. Research shows that no single learning style leads to better learning, however, benefits of certain teaching strategies can only be caught by students with certain learning styles; teaching while meeting different learning styles and orientations enhances teaching effectiveness (Perry 1970; Cross 1976; Kolb 1984; Matthews 1991; Davis 1993).

\section{Simulation Helps Students Move toward Higher Levels of Intellectual Development}

Human learning develops with cognitive development ranging from feeling, watching, and thinking to doing (Kolb 1984). In terms of classroom activities, simulation has been identified as most suitable for students to develop and practice the highest stage of intellectual growth (Fuhrmann and Grasha 1983; Claxton and Murrell 1987; Svnicki and Dixon 1987; Erickson and Strommer 1991).

\section{Simulation Engages Motivation to Learn}

"Effective learning in the classroom depends on the teacher's ability to motivate students and maintain their interests to participate in the course in the first place" (Ericksen 1978, p. 3). General strategies of motivating students include actively involving students to learn through doing, and vary teaching methods to reawaken students' involvement in courses (Forsyth and McMillan 1991), all of which can be achieved through the use of simulation.

\section{Simulator of Network Growth}

The Simulator of Network Growth (SONG), which can be accessed at 〈http://www.ce.umn.edu/ levinson/Song/Dynamics. $\mathrm{html}\rangle$, supports the learning of the transportation network development process. The growth or decline of transportation networks is normally treated as the result of top-down decision making in long-range planning efforts of metropolitan planning organizations (MPOs). However, changes to transportation networks are essentially the result of numerous small decisions by property owners, firms, developers, towns, cities, counties, state department of transportation districts, MPOs, and states in response to market conditions and policy initiatives (Yerra and Levinson 2005). This kind of system behavior demonstrates the characteristics of decentralized systems, where organized patterns and structures can emerge not because of centralized control, but because of the interactions among decentralized system components. In $S O N G$, transportation networks are treated as decentralized systems that demonstrate the property of self-organization. The simulator models behaviors of individual system components (network links) and small decisions, and then demonstrates the patterns resulting from interactions among the component models.

As illustrated in the modeling process of SONG (Fig. 1), $S O N G$ treats each network link as an autonomous agent. The program takes exogenous inputs such as the base network and land use distribution and translates them into traffic flows and speeds on network links through a travel demand model. Those traffic flows and speeds determine the revenue and costs of maintaining and improving the link, and inform the network investment model. When each link has exhausted its resources, the time period is incremented, population grows, land uses are updated, the travel demand is recomputed on the new network, and the process repeats. At the end of the process, data is exported to a visualization tool, which will allow the growth to be seen in a movielike fashion (Yerra and Levinson 2005).

In the interface of SONG, as shown in Fig. 2, users can adjust parameters to change travelers' value of time, their willingness to travel, toll, how revenue and cost change in response to changes in road speed, flow and distance traveled, and how investments are determined based on link performance. By adjusting these parameters, users can test the effects of these factors on the resulting network forms, which are visualized in terms of speeds or volumes on network links represented by different colors and thickness of the links.

An example, shown in Fig. 3, illustrates how SONG works. Fig. 3 demonstrates different network patterns evolved from different elasticity of link maintenance costs to speed change. The initial network is shown in Fig. 3(a), where there are no speed differences across links. Fig. 3(b) displays the resulting network 


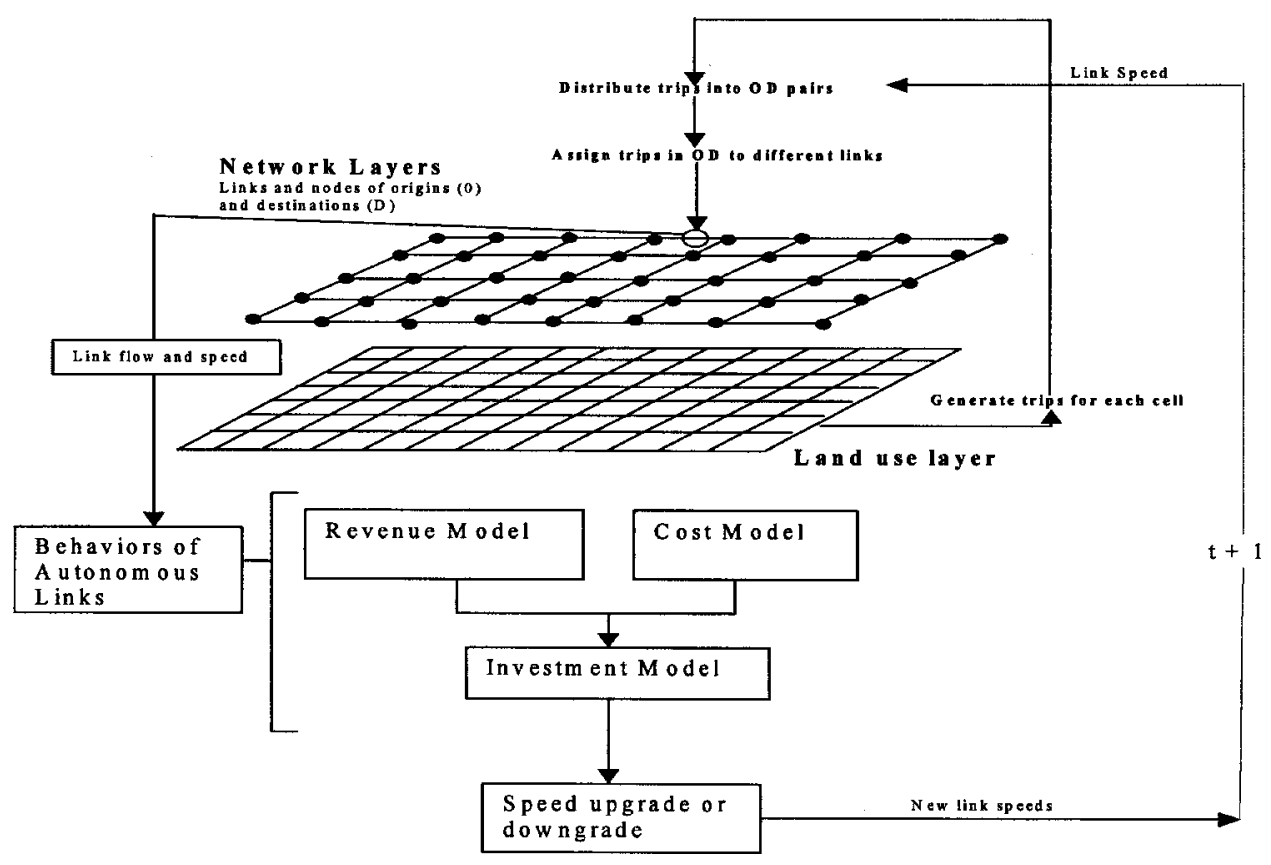

Fig. 1. Modeling process flowchart of $S O N G$

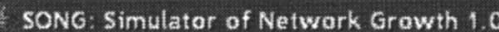

SONO1.0 HelP
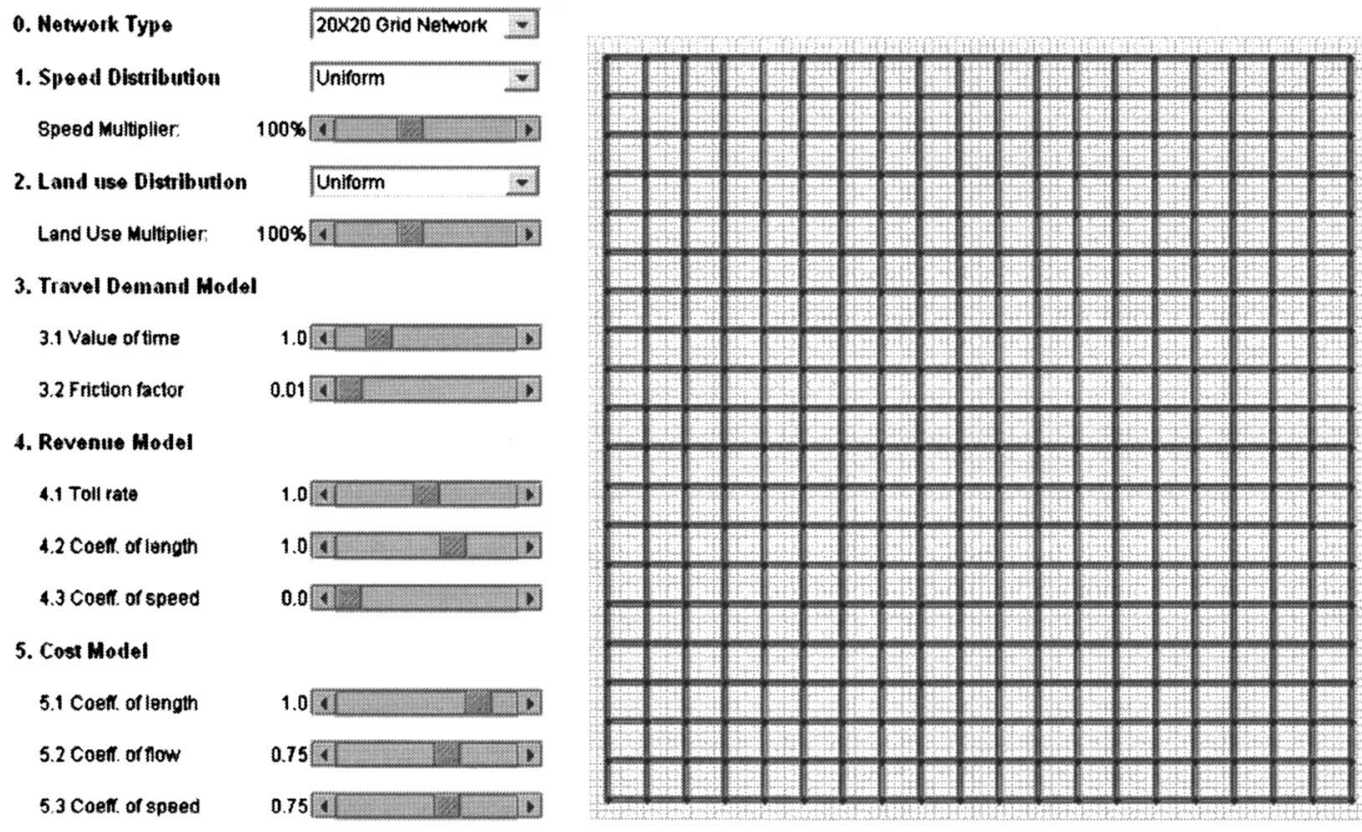

6. Investment Wodel

6.1 Speed impr coefr.

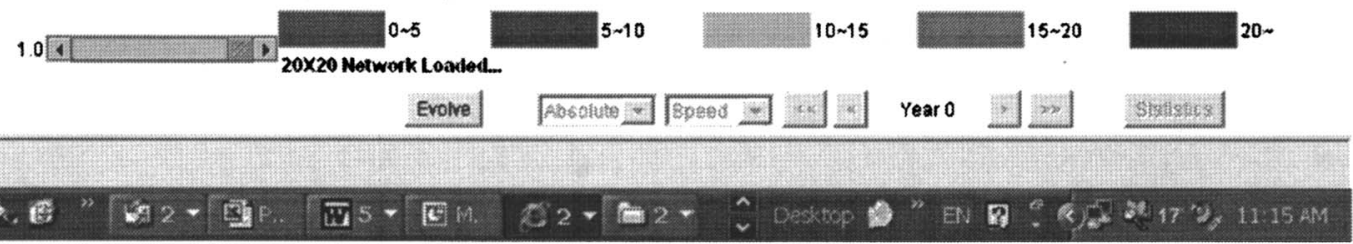

Restore

Java Applet Window

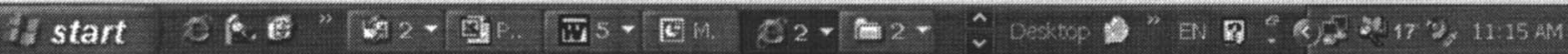

Source: SONG Help file, 2004

Fig. 2. Interface of $S O N G$ 


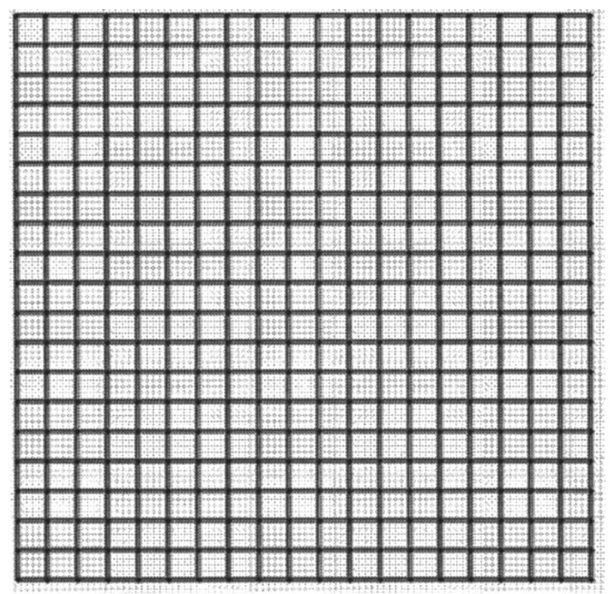

(a) Initial speed distribution (uniform)

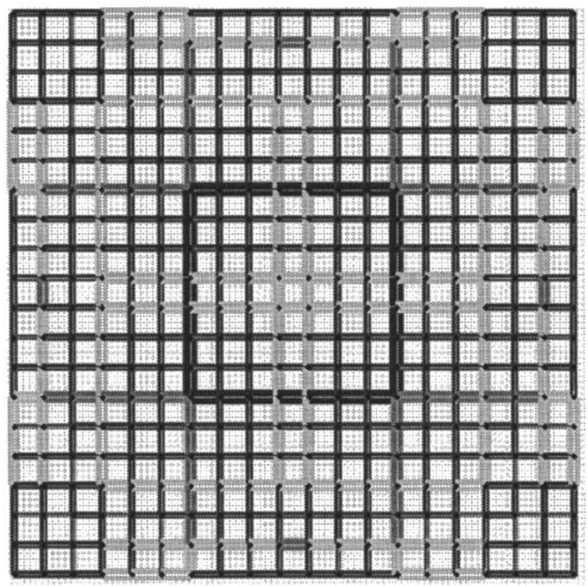

(b) Speed reach equilibrium with economy of scale in speed upgrade (uniform)

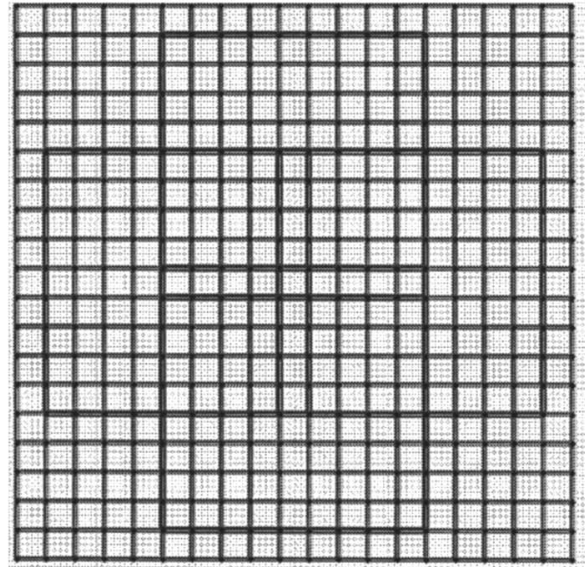

(c) Speed reach equilibrium with diseconomy of scale in speed upgrade (uniform)

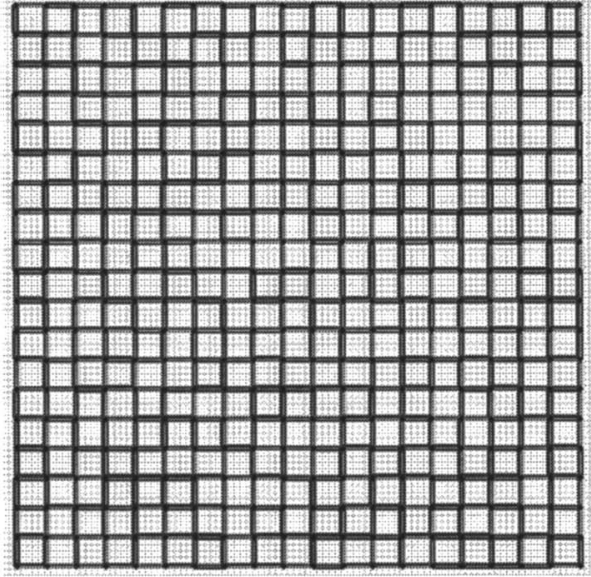

(d) Initial speed distribution (random)

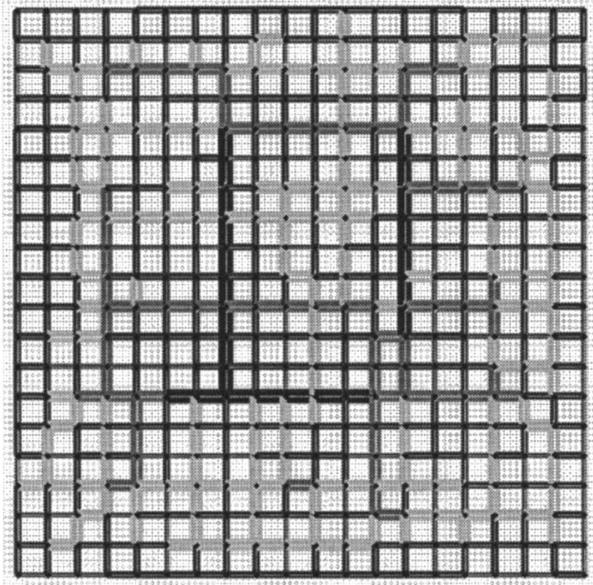

(e) Speed reach equilibrium with economy of scale in speed upgrade (random)

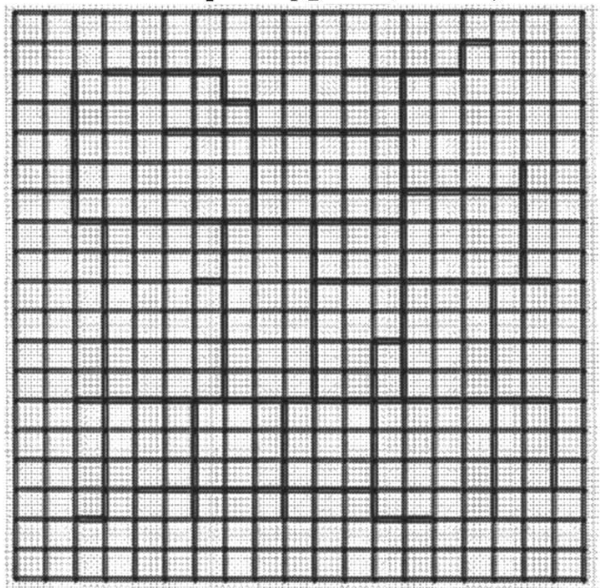

(f) Speed reach equilibrium with diseconomy of scale in speed upgrade (random)

Fig. 3. Effects of cost elasticity to speed changes (uniform versus randomized patterns)

speed pattern with cost elasticity adjusted such that a $1 \%$ increase in speed will lead to less than a $1 \%$ increase in road maintenance costs, indicating an economy of scale in upgrading road speed. Fig. 3(c) shows the resulting network speed pattern with a diseconomy of scale in upgrading road speeds holding all other factors constant.
Users can draw two implications from the simulation: first, hierarchical patterns emerge out of a uniformly laid out network with fewer higher-speed links clustered around the center and a larger number of lower-speed links distributed adjacent to the network borders; and second, economies of scale [Fig. 3(b)] lead to greater investment to increase road speed, and diseconomies of 
scale create fewer incentives for upgrading speed, resulting in generally lower and more uniform speeds across the network [Fig. 3(c)].

The same experiments can be done in a randomized manner as demonstrated in Figs. 3(d-f), where similar network patterns occur except that randomized speed distribution leads to more stochastic network patterns instead of the symmetric patterns shown in Figs. 3(a-c).

Applied in educational settings, $S O N G$ is expected to stimulate students to think and gain new understandings about how transportation networks grow or decline, whether network patterns (e.g., hierarchy) are planned or emergent, and how policy alternatives affect the location of network expansions and contractions. Compared with other simulators or the software packages commonly used in transportation education, $S O N G$ has the following features.

Soft simulation: SONG is a "soft simulation," which "provides a qualitative understanding of a complex system by constructing a simple one that shares the same principle" (Papert 1992). In many cases, simulations are designed to imitate and make predictions about real-world systems as accurately as possible. However, in SONG, more interest is placed on "stimulation" than in "simulation." In developing the simulator for classroom use, the focus is not on a perfect reproduction of the real world, but rather to help students explore the "microworld" of transportation network systems and to stimulate new ways of thinking about the network growth and planning process.

Simpler, easier, and cheaper. Conventional planning software packages, such as EMME/2, TransCAD, and TranPlan, are often cumbersome, difficult to learn, and expensive. SONG is simpler and easier to learn, and is free for students to use. Hence it costs both students and instructors less to incorporate $S O N G$ into the curriculum.

Network growth model. SONG is also distinguished from other transportation simulation programs in that it is a network growth model. So far, the writers have discovered no literature on educational application of network growth models.

Given its features, SONG is expected to have a value in the teaching of transportation network evolution. This study investigates the usefulness and efficacy of SONG as an educational tool by adopting $S O N G$ into a transportation planning/engineering course.

\section{Experiment}

To investigate whether or not the use of $S O N G$ would enhance the learning of transportation network growth, an experiment was conducted on a senior/graduate level course on Transportation Systems Analysis (CE5214) in spring semester 2004 at the Civil Engineering Department, University of Minnesota. The objectives for adopting SONG to classroom education are threefold.

Improve learning outcomes. Besides learning the subject of transportation network growth, SONG is also expected to help students develop soft skills in judgment and problem-solving through the experimental learning obtained in the simulated environment. The particular learning outcomes expected through using SONG include:

- Stimulate new ways of thinking about the dynamics of network development;

- Enhance the ability to draw implications of alternative policies on transportation network form;

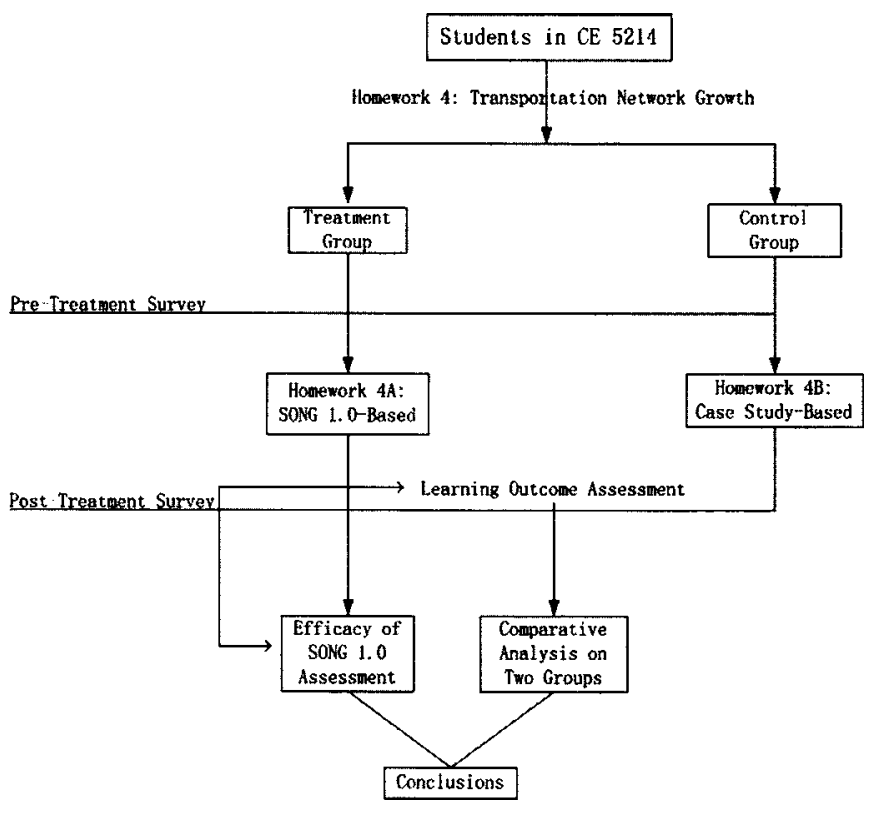

Fig. 4. Experiment design

- Develop understanding of the transportation network development process, the influencing factors, and players;

- Develop an understanding of travel demand modeling process; and

- Develop problem-solving skills and judgment skills in infrastructure investment decision making.

Test hypothesis. The research objective of this experiment is to investigate if the use of simulation can improve the learning outcomes and test the hypothesis that SONG can be an effective tool for enhancing students' learning on the subject of transportation network growth.

Generate guidelines for applying simulation in transportation education. Experience, findings, and lessons learned from this study will be summarized to provide implementation guidelines for attempts to innovate in teaching through the use of simulation.

Transportation Systems Analysis is a 3-credit senior/graduate course. The course objectives are to have students acquire knowledge of travel behavior, travel demand forecasting, and network growth, and to develop context sensitive use of problem-solving and judgment skills necessary for success in the transportation profession as civil engineers and planners. Previously, the teaching used traditional approaches of lecturing, problems, and examinations. While these approaches led to learning by students, they may not fully foster learning and application of knowledge. Hence $S O N G$ is incorporated into this course as an innovation for improving teaching effectiveness. Table 3 summarizes the students' backgrounds.

The experiment incorporates SONG into a homework assignment of CE 5214. The experimental process, shown in Fig. 4, contains three parts: (1) Comparative Study on Two Groups: the experiment randomly divided the class into two groups with the control group receiving the traditional case study-based assignment and the treatment group taking SONG-based assignment (both assignments and related documents are available at $\langle\mathrm{http}: / /$ www.ce.umn.edu/ levinson/Projects/TEL/TEL.html〉). A com- 
Table 1. Comparison of Simulation-Based Assignment versus Case Study-Based Assignment

\begin{tabular}{|c|c|c|}
\hline & $\begin{array}{c}\text { Treatment group } \\
\text { Assignment A: simulation-based }\end{array}$ & $\begin{array}{c}\text { Control group } \\
\text { Assignment B: traditional case study }\end{array}$ \\
\hline Objectives & $\begin{array}{l}\text { Stimulate new way of thinking (how component factors affect the why } \\
\text { Understand principles of transportation network system } \\
\text {-Understand transportation network development process } \\
\text {-Understand travel demand modeling process } \\
\text { •Understand current transportation investment decision-making proc } \\
\text { Develop judgment skill } \\
\text { Develop problem-solving skill }\end{array}$ & $\begin{array}{l}\text { ole) } \\
\text { ess }\end{array}$ \\
\hline Similarity & $\begin{array}{l}\text { Objectives } \\
\text { Incorporate four-step transportation planning model } \\
\text { Explore implications of link (corridor) level changes to the whole netv } \\
\text { Examine implications of alternative transportation policies } \\
\text { Students needs to practice judgment skills and problem-solving skills }\end{array}$ & work system \\
\hline Differences & $\begin{array}{l}\text { Use simulator } \\
\text { Students are able to changes variables, and see consequences } \\
\text { as the results of their actions } \\
\text { Able to see changes in resulting network } \\
\text { Interactive } \\
\text { Analyze autonomous links and explore effects to the whole } \\
\text { Conceptual } \\
\text { "Doing" based }\end{array}$ & $\begin{array}{l}\text { Use case study } \\
\text { Students do not change anything; theiractions do not affect } \\
\text { the results; the data are given } \\
\text { Not able to see (no visualization) } \\
\text { Static } \\
\text { Analyze one link and explore effects tothe whole } \\
\text { Based on true case } \\
\text { "Reading" based }\end{array}$ \\
\hline
\end{tabular}

parative study on the two groups aims to determine whether students learn better with SONG than without it; (2) Assignment Design: As shown in Table 1, the control assignment and treatment assignment are designed such that the objectives, substances, and work loads are of no significant difference. They differ, however, in that the treatment assignment is based on the simulation platform, it allows students to make changes and see consequences of their actions, it allows students to see the visualized outcomes, it is interactive, and allows students to learn through "doing;" and (3) Evaluation: Two surveys and one exam are conducted to assess students' performances and investigate SONG's efficacy as a learning tool.

\section{Evaluation}

As shown in Table 2, the evaluation involves two steps: control students' background differences and other confounding factors, and compare learning outcomes between the two groups. Data for the evaluations are collected from the preassignment survey, the posttreatment survey, and final exam.

Beyond the simulator, many other factors also affect students' learning. An analysis of these factors provides critical information for determining whether the differences in learning outcomes can be attributed to the effects of the simulator. In particular, students' academic background, relevant prior experiences and knowledge, computer proficiency, and learning styles are expected to affect their performance in the assignment.

In this study, self-reported learning styles are assessed with Kolb's (1984) Learning Style Inventory (LSI), and Felder-Silverman's (1988) Index of Learning Styles (ILS). As shown in Fig. 5, LSI is an established tool for learning style assessment; while ILS is developed mainly to assess learning styles of engineering students (Evans et al. 2000). It is expected the educational benefits of SONG are most likely to be captured by students with preferences to learn through watching and doing,
Table 2. Evaluation Design

\begin{tabular}{|c|c|}
\hline Evaluation objectives & Survey questions \\
\hline \multicolumn{2}{|l|}{ Preassignment survey } \\
\hline \multirow[t]{8}{*}{ Confounding factors } & Demographic \\
\hline & Academic background \\
\hline & Professional background \\
\hline & Computer background \\
\hline & Learning style \\
\hline & Prior subject comprehension and thinking \\
\hline & Prior problem solving skill \\
\hline & Prior judgment skill \\
\hline \multicolumn{2}{|l|}{ Postassignment survey } \\
\hline \multirow[t]{5}{*}{ Learning outcomes } & Subject comprehension (thinking) \\
\hline & Judgment skill \\
\hline & Problem solving skill \\
\hline & Time taken to finish the homework \\
\hline & Reflections on learning experiences \\
\hline \multirow{3}{*}{$\begin{array}{l}\text { Efficacy assessment } \\
\text { of } S O N G 1.0 \\
\text { as a learning tool }\end{array}$} & Subjective satisfaction with $S O N G 1.0$ \\
\hline & Learnability of $S O N G 1.0$ \\
\hline & Effectiveness of SONG 1.0 \\
\hline \multirow[t]{3}{*}{ Confounding factors } & Quality of simulator \\
\hline & Quality of the assignment \\
\hline & Quality of TA instruction \\
\hline \multicolumn{2}{|l|}{ Final exam } \\
\hline \multirow[t]{4}{*}{ Learning outcomes } & Subject comprehension \\
\hline & Problem solving skill \\
\hline & Judgmental skills \\
\hline & New ways of thinking \\
\hline
\end{tabular}




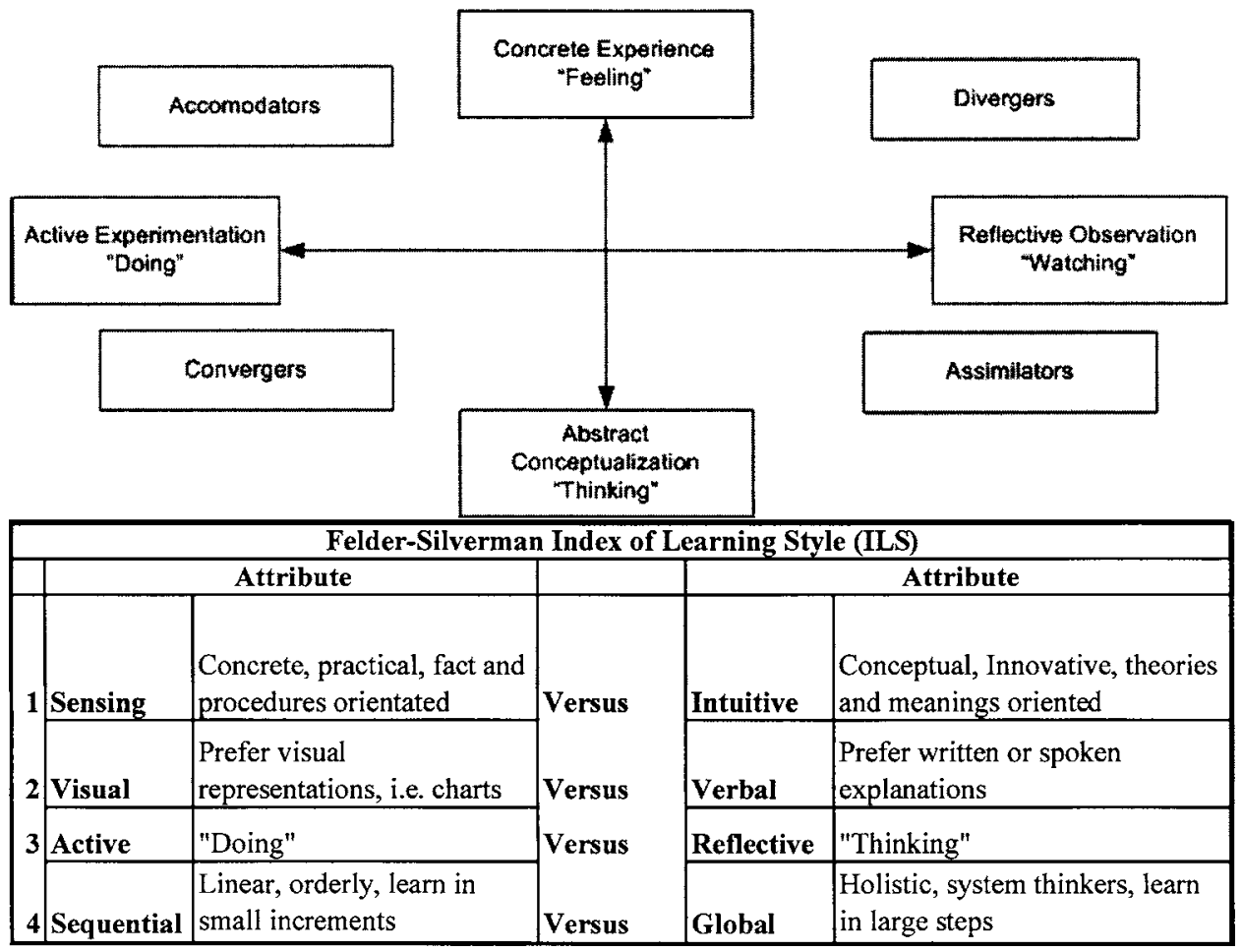

Fig. 5. Kolb Learning Style Inventory (LSI) and Felder-Silverman Index of Learning Style (ILS) (reproduced with permission from Evans et al. 2000). Source: Kolb 1976; Felder and Silverman 1988.

and students who prefer visual and active styles of learning.

With students' background differences and other confounding factors being controlled, students' learning outcomes are compared to determine whether the use of $S O N G$ leads to different learning by the two groups. Learning outcomes are measured with three criteria: (1) time taken to complete the assignment; (2) achievement of learning objectives, including subject understanding, and skills improvement, and (3) students' reflections on the learning experiences with the assignments.

Of 31 students, 27 students finished the homework on time, 26 students responded to the pretreatment survey, and 25 students responded to the posttreatment survey. Results of the assessment on students' background, learning styles, prior knowledge, and prior skills are shown in Table 3.

Demographic, academic, professional background and technical capacity assessment indicates that none of the factors examined are significantly different between the treatment group and the control group; Learning style assessment shows no significant differences between the two groups either. It is also revealed that 15 out of 28 students prefer learning through "watching" and 20 out of 28 students prefer learning through "doing," implying that the use of a simulator matches the learning preferences of the majority of the class; Prior knowledge assessment indicates that the treatment group is significantly less familiar with the travel demand modeling process, and transportation simulation; and Prior skills assessment decomposes and evaluates students' judgment skills and problem-solving skills at a factor level. It is implied that the control group perceives themselves significantly stronger in terms of forming opinions (judgment skill) and developing methods to solve problems (problem-solving skill). The same differences persisted through posttreatment survey.

Learning outcomes are measured in terms of students' perfor- mance, time spent on the assignment, and students' reflections on their assignment learning experience. Student performance is assessed both through surveys in terms of their perceived improvements on skills and subject understanding, and through their performance on the final exam.

Three exam questions test the subjects of travel demand modeling process, network development process, and students' problem-solving skills in infrastructure investment decisionmaking. To assess students' ability to apply the concept learned, students were asked to use examples to illustrate their answers.

The exam grading criteria include: relevance of the answershow closely and clearly the questions were addressed, application of the concept-how well examples are interpreted, and depth of understanding on the subject examined. Depth of learning is assessed in terms of understanding, understanding the subject in different ways, and incorporating learners' own position and perspectives (Romme 2002).

The reason for evaluating students' depth of understanding is that the treatment group is expected to lean toward deeper learning than the control group. Different from surface learning, which "is tied to a specific learning situation given, such as a text, problem, or assignment" (Martin 1999; Romme 2002), a deep learning "goes beyond the given situation or problem and explores the larger issues represented by a particular problem" (Martin 1999). SONG is expected to be more productive and valuable in facilitating deep learning because of the interactive situation and complex interplay of variables provided through the simulation. Results of learning outcome assessment are summarized in Table 4.

Performance assessed through surveys. In terms of students' perceived improvements on subject understanding through the assignment, the treatment group enhanced their understanding sig- 
Table 3. Assessment on Students’ Background, Learning Styles, Prior Subject Understanding, and Prior Skill

\begin{tabular}{|c|c|c|c|c|c|c|c|c|c|}
\hline \multirow[b]{2}{*}{ Student background assessment } & & \multicolumn{2}{|c|}{ Class } & \multicolumn{2}{|c|}{ Treatment } & \multicolumn{2}{|c|}{ Control } & \multirow[b]{2}{*}{$t$} & \multirow[b]{2}{*}{$p$} \\
\hline & & Mean & $\mathrm{Sd}$ & Mean & $\mathrm{Sd}$ & Mean & $\mathrm{Sd}$ & & \\
\hline & Observations & 28 & - & 14 & - & 14 & - & - & - \\
\hline \multirow[t]{4}{*}{ Demographic } & Age & 24.6 & 3.9 & 24.4 & 4.6 & 24.9 & 3.18 & -0.283 & 0.7816 \\
\hline & Gender (counts) & & & & & & & -1.3849 & 0.1894 \\
\hline & Female & 5 & - & 1 & - & 4 & - & - & - \\
\hline & Male & 23 & - & 13 & - & 10 & - & - & - \\
\hline \multirow[t]{16}{*}{ Academic } & Educational level (counts) & & & & & & & 1.1945 & 0.2536 \\
\hline & Graduate & 10 & - & 4 & - & 6 & - & - & - \\
\hline & Undergrad & 16 & - & 8 & - & 8 & - & - & - \\
\hline & Other & 2 & - & 2 & - & 0 & - & - & - \\
\hline & Department (counts) & & & & & & & 0.6183 & 0.547 \\
\hline & Engineering & 24 & - & 11 & - & 13 & - & - & - \\
\hline & Planning & 2 & - & 2 & - & 0 & - & - & - \\
\hline & CTS & 2 & - & 1 & - & 1 & - & - & - \\
\hline & Focus of study (Counts) & & & & & & & 1.7489 & 0.1039 \\
\hline & Transportation & 23 & - & 12 & - & 11 & - & - & - \\
\hline & Other & 4 & - & 1 & - & 3 & - & - & - \\
\hline & Missing & 1 & - & 1 & - & 0 & - & - & - \\
\hline & Research interests (counts) & & & & & & & 1.1466 & 0.2722 \\
\hline & Transportation & 13 & - & 5 & - & 8 & - & - & - \\
\hline & Other & 6 & - & 3 & - & 3 & - & - & - \\
\hline & None & 9 & - & 6 & - & 3 & - & - & - \\
\hline \multirow{5}{*}{$\begin{array}{l}\text { Professional } \\
\text { background }\end{array}$} & Years of relevant experiences & 1.4 & 2.6 & 1.84 & 3.11 & 1 & 1.89 & 0.7887 & 0.4445 \\
\hline & Consider transportation career & & & & & & & 0.844 & 0.4139 \\
\hline & Yes (counts) & 22 & - & 10 & - & 12 & - & - & - \\
\hline & No (counts) & 1 & - & 0 & - & 1 & - & - & - \\
\hline & Missing (counts) & 5 & - & 4 & - & 1 & - & - & - \\
\hline \multirow[t]{2}{*}{ Technical capacity } & Weekly computer usage & 27.9 & 14 & 24.07 & 14.75 & 31.79 & 12.5 & -2.0565 & 0.0604 \\
\hline & Computer proficiency & 3.1 & 0.54 & 2.93 & 0.62 & 3.21 & 0.43 & -1.7489 & 0.1039 \\
\hline \multicolumn{10}{|l|}{ Learning style assessment } \\
\hline & Observations & 28 & - & 14 & - & 14 & - & - & - \\
\hline & Kolb's learning styles (counts) & & & & & & & & \\
\hline & Feeling & 7 & - & 3 & - & 4 & - & -0.4341 & 0.6714 \\
\hline & Watching & 15 & - & 8 & - & 7 & - & 0.4341 & 0.6714 \\
\hline & Thinking & 6 & - & 3 & - & 3 & - & 0 & 1 \\
\hline & Doing & 20 & - & 10 & - & 10 & - & 0 & 1 \\
\hline & Felder-Silverman (scale 1-5) & & & & & & & & \\
\hline & Sensing versus intuitive & 2.89 & 0.96 & 2.86 & 0.86 & 2.93 & 1.07 & -0.2012 & 0.8436 \\
\hline & Visual versus verbal & 2.36 & 1.03 & 2.43 & 1.09 & 2.29 & 0.99 & 0.3661 & 0.7202 \\
\hline & Active versus reflective & 2.21 & 0.96 & 2.29 & 0.99 & 2.14 & 0.95 & 0.4579 & 0.6546 \\
\hline & Sequential versus global & 2.46 & 1.1 & 2.71 & 1.14 & 2.21 & 1.05 & 1.2419 & 0.2362 \\
\hline & Innovative strategies motivate learning & 2.21 & 0.69 & 2.21 & 0.8 & 2.21 & 0.58 & 0 & 1 \\
\hline & Constructionist versus instructionist & 2.71 & 0.94 & 2.64 & 1 & 2.79 & 0.89 & -0.3958 & 0.6987 \\
\hline \multicolumn{10}{|l|}{ Prior understanding of the subject } \\
\hline & Observations & 28 & - & 14 & - & 14 & - & - & - \\
\hline & Average number of relevant courses & 1.54 & 0.84 & 1.57 & 0.85 & 1.71 & 1.14 & -0.4136 & 0.6859 \\
\hline & Familiarity with 4 -step model (scale $1-5$ ) & 2.86 & 1.35 & 2.21 & 1.37 & 3.5 & 1.02 & -3.026 & $0.0097^{\mathrm{a}}$ \\
\hline & $\begin{array}{l}\text { Familiarity with transportation simulation } \\
\text { (scale } 1-5)\end{array}$ & 2.82 & 1.22 & 2.21 & 1.19 & 3.43 & 0.94 & -2.9732 & $0.0108^{\mathrm{b}}$ \\
\hline \multicolumn{10}{|l|}{ Prior skill assessment } \\
\hline Observations & & 28 & - & 14 & - & 14 & - & - & - \\
\hline \multirow[t]{2}{*}{$\begin{array}{l}\text { Judgment skill } \\
\text { (scale } 1-5)\end{array}$} & $\begin{array}{l}\text { Ability to identify relationship of components in } \\
\text { transportation systems }\end{array}$ & 3.07 & 1.02 & 2.71 & 0.91 & 3.43 & 1.02 & -1.735 & 0.1064 \\
\hline & $\begin{array}{l}\text { Ability to form opinion regarding transportation } \\
\text { issues }\end{array}$ & 3.71 & 0.94 & 3.43 & 0.94 & 4 & 0.88 & -2.28 & $0.0401^{b}$ \\
\hline
\end{tabular}




\begin{tabular}{|c|c|c|c|c|c|c|c|c|c|}
\hline \multirow[b]{2}{*}{ Student background assessment } & & \multicolumn{2}{|c|}{ Class } & \multicolumn{2}{|c|}{ Treatment } & \multicolumn{2}{|c|}{ Control } & \multirow[b]{2}{*}{$t$} & \multirow[b]{2}{*}{$p$} \\
\hline & & Mean & $\mathrm{Sd}$ & Mean & $\mathrm{Sd}$ & Mean & $\mathrm{Sd}$ & & \\
\hline \multirow{6}{*}{$\begin{array}{l}\text { Problem-solving skills } \\
\text { (scale } 1-5)\end{array}$} & $\begin{array}{l}\text { Ability to evaluate alternatives by discerning } \\
\text { and comparing strength and weakness }\end{array}$ & 3.5 & 0.75 & 3.5 & 0.65 & 3.5 & 0.85 & 0 & 1 \\
\hline & $\begin{array}{l}\text { Ability to identify information needed to solve } \\
\text { a problem }\end{array}$ & 3.43 & 0.92 & 3.29 & 1.07 & 3.57 & 0.76 & -0.888 & 0.3909 \\
\hline & $\begin{array}{l}\text { Ability to apply an abstract concept or idea to a } \\
\text { real problem or situation }\end{array}$ & 3.18 & 0.82 & 3.21 & 0.8 & 3.14 & 0.86 & 0.268 & 0.7929 \\
\hline & $\begin{array}{l}\text { Your ability to divide problem into manageable } \\
\text { components }\end{array}$ & 3.8 & 0.84 & 3.75 & 0.94 & 3.86 & 0.77 & -0.4 & 0.696 \\
\hline & $\begin{array}{l}\text { Your ability to develop several methods which } \\
\text { might be used to solve a problem }\end{array}$ & 3.18 & 0.72 & 3 & 0.68 & 3.36 & 0.74 & -2.11 & $0.0548^{\mathrm{c}}$ \\
\hline & $\begin{array}{l}\text { Your ability to use established criteria to } \\
\text { evaluate and priotize solution }\end{array}$ & 3.64 & 0.73 & 3.36 & 0.74 & 3.93 & 0.62 & -2.104 & $0.0554^{\mathrm{c}}$ \\
\hline
\end{tabular}

${ }^{\mathrm{a}}$ Significant at $90 \%$ confidence level.

${ }^{\mathrm{b}}$ Significant at $95 \%$ confidence level.

${ }^{\mathrm{c}}$ Significant at $99 \%$ confidence level.

nificantly better than the control group about development process of network pattern. In terms of skill improvements assessed by comparing perceived skill changes through the assignment between the two groups, the treatment group indicated significantly more improvements than the control group in terms of their ability to identify the relationship of components in transportation systems and the ability to use established criteria to evaluate and prioritize solutions.

Performance assessed through final exam questions. In terms of subject understanding, which was assessed through questions on four-step travel demand modeling, and on the development process of a network pattern, the treatment and control groups were found to perform equally well. In terms of students' decision-making and problem-solving skills, the overall performance of the treatment group is found to be significantly better than the control group.

Time spent on completing the assignment and students' reflections on the experiences of learning through the experimental homework is another aspect of performance being examined. After the experiment, students were surveyed about the time they spent on completing the assignment, their satisfaction with the amount of time they have spent, as well as their effectiveness in completing the assignment. No significant differences between the treatment and control groups were found in these regards. Students' reflections on the learning experiences, which are informative as for how well they learned and how helpful was the teaching strategy they experienced, are of no significant differences between the two groups either.

Learning outcomes versus students' characteristics. To explore what kind of students gain most from the simulation-based assignment, regressions were run between students' performances and several explanatory variables on students' characteristics. As shown in Table 5, taking simulation-based assignment is positively and significantly associated with students' self-reported improvements in their understanding of the development of network patterns. Contrary to expectation, students who prefer learning through thinking (reflective learning) instead of learning through doing (active learning) are positively associated with understanding improvements on this subject with statistical significance. At the $99 \%$ confidence level, simulation treatment is positively associated with students' perceived improvements on the ability to identify relationships of components in transportation systems.
Students' relevant working experience is negatively correlated with improvement on this particular skill.

Students' performance on the exam is also associated with some of their characteristics as shown in Table 5. In terms of the question on network development pattern, students' ability to incorporate their own perspective into the answers is positively related to their age and relevant working experiences. Students who are more oriented to global and holistic thinking and those who prefer constructing their own knowledge are more likely to perform well on this regard. In terms of students' decision-making skills, it is found that students with more relevant courses taken before are more likely to perform better on this question; and students with a preference for constructing their own knowledge and who have taken more relevant courses showed stronger ability to understand the subject in different ways.

\section{Conclusions and Lessons Learned}

Findings from this research can be summarized as follows: first, the use of $S O N G$ is effective in improving students' performance in some areas of learning. With SONG, students performed significantly better in learning network development patterns and in developing their ability to identify a relationship of components in transportation systems, the ability to establish criteria to evaluate and prioritize solutions, in developing decision-making skills, and in-depth understanding of the investment decision making process.

Second, as summarized in Table 6, those who performed better in certain learning areas possess certain characteristics in terms of their age, education level, computer proficiency, prior experience, as well as learning styles. Hence for different learning outcomes pursued, it can be effective to apply simulation to learners of appropriate age, educational level, learning styles, and prior knowledge.

Third, for most of the learning outcomes assessed, the treatment group performed as well as the control group. As revealed from the surveys, the lower-than-expected learning outcomes achieved by the treatment group can be explained by three factors: (1) in terms of prior knowledge and skills, the control group had significant advantages over the treatment group as indicated 
Table 4. Learning Outcome Assessment

Perceived improvements on subject understanding (assessed through surveys)

\begin{tabular}{|c|c|c|c|c|c|c|c|c|c|c|}
\hline & & \multicolumn{2}{|c|}{ Class } & \multicolumn{2}{|c|}{ Treatment } & \multicolumn{2}{|c|}{ Control } & \multirow{2}{*}{$\begin{array}{l}\text { Expected } \\
\text { sign }\end{array}$} & \multirow[b]{2}{*}{$t$} & \multirow[b]{2}{*}{$p$} \\
\hline & & Mean & $\mathrm{Sd}$ & Mean & $\mathrm{Sd}$ & Mean & $\mathrm{Sd}$ & & & \\
\hline & Observations & 25 & - & 14 & - & 11 & - & & - & - \\
\hline & Four-step planning model ${ }^{\mathrm{a}, \mathrm{b}}$ & 3.347 & 1.07 & 3 & 1.28 & 3.372 & 0.65 & & -1.7 & 0.1048 \\
\hline & Transportation simulation ${ }^{\mathrm{a}, \mathrm{b}}$ & 3.608 & 1.076 & 4 & 0.96 & 3 & 1 & & 2.4 & 0.258 \\
\hline & $\begin{array}{l}\text { Development of network } \\
\text { pattern }^{\mathrm{a}, \mathrm{b}}\end{array}$ & 3.167 & 1.129 & 3.615 & 1.12 & 2.636 & 0.92 & & 2.31 & 0.0309 \\
\hline \multicolumn{11}{|c|}{ Perceived skill improvement assessment (assessed through surveys) } \\
\hline & Observations & 20 & - & 12 & - & 8 & - & & - & - \\
\hline \multirow[t]{3}{*}{$\begin{array}{l}\text { Improvements in } \\
\text { judgment skill }{ }^{\mathrm{a}, \mathrm{b}}\end{array}$} & $\begin{array}{l}\text { Ability to identify relationship of } \\
\text { components in transportation } \\
\text { systems }\end{array}$ & 0.3 & 1.128 & 0.5833 & 1.24 & -0.13 & 0.8 & + & 1.41 & $0.0877^{\mathrm{C}}$ \\
\hline & $\begin{array}{l}\text { Ability to form opinion regarding } \\
\text { transportation issues }\end{array}$ & 6.2 & 0.6958 & 0.25 & 0.87 & 0.125 & 0.4 & + & 0.38 & 0.3525 \\
\hline & $\begin{array}{l}\text { Ability to evaluate alternatives by } \\
\text { discerning and comparing } \\
\text { strength and weakness }\end{array}$ & 0.35 & 1.0399 & 0.25 & 1.06 & 0.5 & 1.1 & + & -0.5 & 0.6941 \\
\hline \multirow{5}{*}{$\begin{array}{l}\text { Improvements in } \\
\text { problem- } \\
\text { solving skills }\end{array}$} & $\begin{array}{l}\text { Ability to identify information } \\
\text { needed to solve a problem }\end{array}$ & 0.35 & 1.1821 & 0.25 & 1.42 & 0.5 & 0.8 & + & -0.5 & 0.6722 \\
\hline & $\begin{array}{l}\text { Ability to apply an } \\
\text { abstractconcept or idea to a } \\
\text { realproblem or situation }\end{array}$ & 0.2 & 1.005 & 0.3333 & 1.15 & 0 & 0.8 & + & 0.72 & 0.2412 \\
\hline & $\begin{array}{l}\text { Your ability to divideproblem } \\
\text { into manageablecomponents }\end{array}$ & -0.175 & 0.907 & -0.2917 & 1.01 & 0 & 0.8 & + & 0 & 0.5 \\
\hline & $\begin{array}{l}\text { Your ability to developseveral } \\
\text { methods which mightbe used to } \\
\text { solve a problem }\end{array}$ & 0.35 & 0.9333 & 0.1666 & 0.72 & 0.625 & 1.2 & + & -1.1 & 0.8529 \\
\hline & $\begin{array}{l}\text { Your ability to useestablished } \\
\text { criteria toevaluate and prioritize } \\
\text { solution }\end{array}$ & 0.1 & 0.7881 & 0.3333 & 0.65 & -0.25 & 0.9 & + & 1.7 & $0.0531^{\mathrm{c}}$ \\
\hline
\end{tabular}

Performance assessed through the exam

Subject understanding on the development of network patterns

\begin{tabular}{|c|c|c|c|c|c|c|c|c|c|}
\hline Relevance & $\begin{array}{l}\text { How close and clear thequestions } \\
\text { were addressed }\end{array}$ & 3.577 & 0.643 & 3.5 & 0.76 & 3.73 & 0.47 & -0.87 & 0.3936 \\
\hline \multirow{3}{*}{$\begin{array}{l}\text { Depth of } \\
\text { understanding }\end{array}$} & Subject understanding & 3.538 & 0.51 & 3.5 & 0.52 & 3.635 & 0.5 & -0.66 & 0.5157 \\
\hline & $\begin{array}{l}\text { Understand the subject indifferent } \\
\text { ways }\end{array}$ & 3.423 & 0.578 & 3.57 & 0.64 & 3.27 & 0.46 & 1.29 & 0.2103 \\
\hline & $\begin{array}{l}\text { Incorporate learners' } \\
\text { ownpositions (perspectives) }\end{array}$ & 3.46 & 0.581 & 3.64 & 0.5 & 3.27 & 0.64 & 1.62 & 0.1189 \\
\hline $\begin{array}{l}\text { Concept } \\
\text { application }\end{array}$ & $\begin{array}{l}\text { How well the examples } \\
\text { areinterpreted }\end{array}$ & 3.11 & 0.82 & 3.2 & 0.8 & 3.09 & 0.83 & 0.38 & 0.7105 \\
\hline Composite score & & 17.1 & 2.32 & 17.4 & 2.59 & 17 & 1.9 & 0.46 & 0.6504 \\
\hline \multicolumn{10}{|c|}{ Decision making and problem-solving skills } \\
\hline Relevance & $\begin{array}{l}\text { How close and clear thequestions } \\
\text { were addressed }\end{array}$ & 3.69 & 0.47 & 3.71 & 0.47 & 3.64 & 0.5 & 0.4 & 0.693 \\
\hline \multirow{3}{*}{$\begin{array}{l}\text { Depth of } \\
\text { understanding }\end{array}$} & Subject understanding & 3.5 & 0.58 & 3.64 & 0.5 & 3.36 & 0.67 & 1.19 & 0.245 \\
\hline & $\begin{array}{l}\text { Understand the subject indifferent } \\
\text { ways }\end{array}$ & 3 & 0.89 & 3.36 & 0.63 & 2.54 & 1.03 & 2.42 & $0.024^{\mathrm{d}}$ \\
\hline & $\begin{array}{l}\text { Incorporate learners' } \\
\text { ownpositions (perspectives) }\end{array}$ & 3.2 & 0.87 & 3.57 & 0.51 & 2.91 & 1.14 & 1.95 & $0.063^{\mathrm{c}}$ \\
\hline $\begin{array}{l}\text { Concept } \\
\text { application }\end{array}$ & $\begin{array}{l}\text { How well the examples } \\
\text { areinterpreted }\end{array}$ & 3.54 & 0.64 & 3.57 & 0.65 & 3.45 & 0.69 & 0.44 & 0.666 \\
\hline Composite score & & 17 & 2.75 & 17.86 & 2.44 & 15.91 & 2.98 & 1.8 & 0.086 \\
\hline
\end{tabular}

${ }^{\mathrm{a}}$ Values shown in scale 1 to 5 representing degree of agreement on improvements of subject understanding or skill improvements (1: strongly disagree; 5 : strongly agree).

${ }^{\mathrm{b}}$ Improvements are represented by the differences of ratings between pre- and post-surveys.

${ }^{\mathrm{c}}$ Significant at $90 \%$ confidence level.

${ }^{\mathrm{d}}$ Significant at $95 \%$ confidence level. 
Table 5. Perceived Improvements of Understanding and Skills versus Students' Characteristics and Exam Performance versus Students' Characteristics

\begin{tabular}{|c|c|c|c|c|c|c|c|c|c|c|c|c|c|c|c|}
\hline \multirow{4}{*}{$\begin{array}{l}\text { Explanatory } \\
\text { variables }\end{array}$} & nts of unders & nding and & ills versu & \multicolumn{3}{|c|}{$\begin{array}{c}\text { students' characteristics } \\
\text { Improvements } \\
\text { on the ability } \\
\text { to identify } \\
\text { relationships of } \\
\text { components in } \\
\text { transportation } \\
\text { systems }\end{array}$} & \multicolumn{9}{|c|}{ Performance on the exam versus students' characteristics } \\
\hline & \multirow{2}{*}{\multicolumn{3}{|c|}{$\begin{array}{l}\text { Understanding } \\
\text { improvement } \\
\text { on the } \\
\text { development } \\
\text { of network } \\
\text { patterns }\end{array}$}} & \multirow{2}{*}{\multicolumn{3}{|c|}{$\begin{array}{l}\text { Improvements } \\
\text { on the ability } \\
\text { to identify } \\
\text { relationships of } \\
\text { components in } \\
\text { transportation } \\
\text { systems }\end{array}$}} & \multirow{2}{*}{\multicolumn{3}{|c|}{$\begin{array}{l}\text { Development } \\
\text { of network } \\
\text { patterns } \\
\text { Ability to } \\
\text { incorporate own } \\
\text { perspectives }\end{array}$}} & \multicolumn{6}{|c|}{ Decision-making skills } \\
\hline & & & & & & & & & & \multicolumn{3}{|c|}{$\begin{array}{c}\text { Overall } \\
\text { performance }\end{array}$} & \multicolumn{3}{|c|}{$\begin{array}{l}\text { Ability to } \\
\text { understand } \\
\text { subject in } \\
\text { different ways }\end{array}$} \\
\hline & Coefficient & $t$ & $p>|t|$ & Coefficient & $t$ & $p>|t|$ & Coefficient & $t$ & $p>|t|$ & Coefficient & $t$ & $p>|t|$ & Coefficient & $t$ & $p>|t|$ \\
\hline $\begin{array}{l}\text { Group } \\
(1=\text { treatment, } \\
0=\text { otherwise })\end{array}$ & 1.72452 & 2.61 & $0.028^{\mathrm{b}}$ & 1.61008 & 3.54 & $0.005^{\mathrm{a}}$ & 0.19441 & 0.76 & 0.462 & 1.7952 & 1.31 & 0.219 & 0.6424 & 1.73 & 0.114 \\
\hline Age & 0.2178 & 1.05 & 0.321 & 0.15159 & 1.06 & 0.312 & 0.16321 & 2.51 & $0.031^{\mathrm{b}}$ & 0.2969 & 0.85 & 0.416 & 0.0562 & 0.59 & 0.567 \\
\hline Education level & 0.16305 & 0.49 & 0.638 & -0.3795 & -1.51 & 0.161 & 0.22907 & 1.29 & 0.227 & 1.3934 & 1.46 & 0.176 & 0.4308 & 1.66 & 0.128 \\
\hline $\begin{array}{l}\text { Working } \\
\text { Experience }\end{array}$ & -0.2711 & -0.88 & 0.402 & -0.3945 & -1.84 & $0.095^{\mathrm{a}}$ & -0.1759 & -2.63 & $0.025^{\mathrm{b}}$ & -0.488 & -1.36 & 0.204 & -1.2726 & -1.31 & 0.221 \\
\hline Computer usage & 0.02188 & 1.04 & 0.324 & 0.01092 & 0.67 & 0.515 & -0.0032 & -0.32 & 0.755 & -0.008 & -0.15 & 0.885 & -0.0028 & -0.19 & 0.853 \\
\hline $\begin{array}{l}\text { Learning style: } \\
\text { visual versus } \\
\text { verbal }\end{array}$ & 0.12217 & 0.37 & 0.721 & 0.25479 & 1.19 & 0.26 & 0.07286 & 0.67 & 0.518 & -0.194 & -0.33 & 0.747 & -0.0745 & -0.47 & 0.648 \\
\hline $\begin{array}{l}\text { Learning style: active } \\
\text { versus reflective }\end{array}$ & 0.57694 & 2.23 & $0.053^{b}$ & -0.0911 & 1.19 & 0.26 & -0.191 & -1.35 & 0.207 & 0.2125 & 0.28 & 0.786 & 0.1748 & 0.85 & 0.417 \\
\hline $\begin{array}{l}\text { Learning style: Sequential } \\
\text { versus global }\end{array}$ & - & - & - & - & - & - & 0.61342 & 2.89 & $0.016^{\mathrm{b}}$ & 1.3457 & 1.18 & 0.266 & 0.4825 & 1.56 & 0.15 \\
\hline $\begin{array}{l}\text { Innovation } \\
\text { motivate learning } \\
\text { or not }\end{array}$ & -0.9687 & -0.23 & 0.826 & -0.1376 & -0.5 & 0.625 & 0.14325 & 0.96 & 0.36 & -0.047 & -0.06 & 0.954 & 0.1892 & 0.87 & 0.406 \\
\hline Constructionism & - & - & - & - & - & - & 0.3548 & 1.9 & $0.087^{\mathrm{b}}$ & 1.7609 & 1.75 & 0.111 & 0.6201 & 2.27 & $0.046^{\mathrm{b}}$ \\
\hline $\begin{array}{l}\text { Number of } \\
\text { elevant courses }\end{array}$ & 0.07089 & 0.33639 & 0.21 & 0.12702 & 0.54 & 0.601 & 0.02898 & 0.19 & 0.854 & 1.6189 & 1.96 & $0.078^{\mathrm{a}}$ & 0.4377 & 1.96 & $0.079^{\mathrm{a}}$ \\
\hline \multirow[t]{2}{*}{ Constant } & -5.1929 & -0.88 & 0.401 & -3.607 & -0.87 & 0.403 & -3.0626 & -1.2 & 0.257 & -5.015 & -0.37 & 0.722 & -3.8816 & -1.05 & 0.32 \\
\hline & \multicolumn{3}{|c|}{$R^{2}=0.6421$, obs $=19$} & \multicolumn{3}{|c|}{$R^{2}=0.75$, obs $=20$} & \multicolumn{3}{|c|}{${ }^{\mathrm{a}} R^{2}=0.7052$, obs $=23$} & \multicolumn{6}{|c|}{${ }^{\mathrm{a}} R^{2}=0.7439, \mathrm{obs}=23$} \\
\hline
\end{tabular}

${ }^{a}$ Significant at $90 \%$ confidence level.

${ }^{b}$ Significant at $95 \%$ confidence level.

ก Significant at $95 \%$ confidence level. 
Table 6. Summary of Characteristics of Students and Learning Outcomes Achieved with Treatment Group Performing Significantly Better

\begin{tabular}{|c|c|c|c|c|c|}
\hline & \multicolumn{5}{|c|}{ Learning outcomes } \\
\hline & $\begin{array}{c}\text { Subject } \\
\text { understanding }\end{array}$ & Judgment skill & $\begin{array}{l}\text { Decision-making } \\
\text { skill }\end{array}$ & $\begin{array}{l}\text { Decision-making } \\
\text { skill }\end{array}$ & $\begin{array}{l}\text { In-depth subject } \\
\text { understanding }\end{array}$ \\
\hline Characteristics & $\begin{array}{c}\text { Development } \\
\text { process of network } \\
\text { patterns }\end{array}$ & $\begin{array}{l}\text { Ability to identify } \\
\text { relationships of } \\
\text { components in } \\
\text { transportation } \\
\text { systems }\end{array}$ & $\begin{array}{l}\text { Understand the } \\
\text { investment process } \\
\text { in different way }\end{array}$ & $\begin{array}{c}\text { In-depth } \\
\text { understanding on the } \\
\text { decision-making } \\
\text { process }\end{array}$ & $\begin{array}{l}\text { Incorporate learners' } \\
\text { own perspectives in } \\
\text { understanding the } \\
\text { development process of } \\
\text { network patterns }\end{array}$ \\
\hline Treatment or not & Yes & Yes & & & \\
\hline Age & & & & & Older \\
\hline \multicolumn{6}{|l|}{ Education level } \\
\hline Working experiences & & Less & & & Less \\
\hline \multicolumn{6}{|l|}{ Computer usage } \\
\hline \multicolumn{6}{|l|}{ Learning style: sensing versus intuitive } \\
\hline \multicolumn{6}{|l|}{ Learning style: visual versus verbal } \\
\hline Learning style: active versus reflective & reflective & & & & \\
\hline Learning style: sequential versus global & & & & & Global \\
\hline \multicolumn{6}{|l|}{ Innovation motivate learning or not } \\
\hline Constructionism versus instructionism & & & Constructionism & & Constructionism \\
\hline Number of relevant courses & & & More & More & \\
\hline
\end{tabular}

in the background assessment; (2) design of SONG: "a good educational simulator depends on its complexity and feedback" (Billhardt 2004), while this study indicated that the messages SONG sent were not clear or self-explanatory to the treatment group. It is also indicated that $S O N G$ was not complex enough to incorporate some of the real-world situations students were interested to test; and (3) in terms of course design, insufficiency of instruction and supporting information, as well as lack of clarity in instruction and supporting information, were indicated by the treatment group as problems with learning; additionally, timing and workload were indicated as problems since the assignment was near the semester's end, when students are likely to be overloaded, introducing pressure as another confounding factor to this study.

Issues with course design and SONG's usability created a barrier to learning and prevented students from capturing the full educational benefits of SONG. This provides valuable lessons for guiding future practice in adopting simulation into an educational setting:

- Provide reasonable complexity of simulator;

- Feedback from simulators needs to be unambiguous and selfexplanatory;

- Interactive instruction is desirable: To help students learn simulators, interactive laboratory instruction is more effective in removing technical barriers than one-way lecturing;

- Proper work load and timing: Work load and timing of the assignment needs to be carefully designed so that students can be given more time to "play," and the "fun" of simulation is more likely to materialize;

- Clear assignment instruction: Be specific about the tasks students need to fulfill the assignments. This creates effective orientation of the substance students are expected to learn from the simulator; and

- Maintain sufficiency of instructions and supporting information.

Future use of the SONG simulator should address these issues, including perhaps using the simulator at or near the beginning of the course, rather than at the end, so that students can see the whole before the parts (costs, revenues, travel demand, invest- ment) are disentangled as the course gets deeper. This too should be followed up with an evaluation and compared with these results, to ascertain whether those changes improved learning outcomes as posited.

\section{References}

Alavi, M., et al. (1997). "Using information technology to add value to management education." Acad. Manage J., 40(6), 1310-1333.

Aldrich, C. (2003). Simulations and the future of learning: An innovative (and perhaps revolutionary) approach to e-learning, Pfeiffer.

Billhardt, B. (2004). "The promise of on-line simulations." MediaTec Publishing Inc. 〈http://www.clomedia.com/content/templates/ clo_feature.asp?; articleid =382\&zoneid=29 $($ Feb. 2004).

Claxton, C. S., and Murrell, P. H., eds. (1987). "Learning styles: Implications for improving education practices." ASHE-ERIC Higher Education Rep., 4, Association for the study of Higher Education, Washington, D.C., 79.

Cross, K. P. (1976). Accent on learning: Improving instruction and reshaping curriculum, Jossey-Bass, San Francisco.

Davis, B. G. (1993). Tools for teaching, Jossey-Bass, San Francisco.

Dreyfus, L., and Dreyfus, S. E. (1986). Mind over machine: The power of human intuition and expertise in the era of the computer, Basil Blackwell, Oxford.

Drew, D. R. (1968). Traffic flow theory and control, McGraw-Hill, New York.

Ericksen, S. C. (1978). "The Lecture.” Memo to the Faculty, no. 60, Ann Arbor: Center for Research on Teaching and Learning, Univ. of Michigan.

Erickson, B. L., and Strommer, D. W. (1991). Teaching college freshmen, Jossey-Bass, San Francisco.

Evans, R. M., Murray, S. L., Daily, M., and Hall, R. H. (2000). "Effectiveness of an internet-based graduate engineering management course." Akust. Zh., 89(1), 63-71.

Felder, R. M., and Silverman, L. K. (1988). "Learning and teaching styles in engineering education." Eng. Educ., 78(7), 674-681.

Flyvbjerg, B. (2001). Making social science matter: Why social inquiry fails and how it can succeed again, Cambridge University Press, New York. 
Forsyth, D. R., and McMillan, J. H. (1991). "Why do learners learn? Answers offered by current theories of motivation." Approaching instructional problems through theoretical perspectives: New directions for teaching and learning, R. J. Menges \& M. Svinicki, Eds., JosseyBass, San Francisco, 44, 39-52.

Fuhrmann, B. S., and Grasha, A. F. (1983). A practical handbook for college teachers, Little, Brown, Boston.

Johnson, D. W., Johnson, R. T., and Smith, K. A. (1998). Active learning: Cooperation in the college classroom.

Kolb, D. A. (1976). Learning style inventory technical manual, McBer, Boston.

Kolb, D. A. (1984). Experiential learning: Experience as the source of learning and development, Prentice-Hall Inc., Englewood Cliffs, N.J.

Lerman, S. R. (2002). "Some criteria for the evaluation of multimedia computer applications." 〈http://design.chosun.ac.kr/ddl/hdb/data/mul/ lerman2.htm〉 (April 2004).

Lowman, J. (2001). Mastering the techniques of teaching, Jossey-Bass, San Francisco.

Martin, E. (1999). Changing academic work, Open University Press, Buckingham.

Matthews, D. B. (1991). "The effects of learning styles on grades of first-year college students." Res. Higher Educ., 32(3), 253-268.
McKeachie, W. (1986). "Meeting a class for the first time." Teaching tips: A guidebook for the beginning college teacher, 8th Ed., D.C. Heath and Company, Lexington, Mass. 18-24.

Papert, S. (1992). The children's machine: Rethinking school in the age of the computer.

Perry, W. (1970). Forms of intellectual and ethical development in the college years: A scheme, Holt, Reinhart \& Winston, New York.

Piaget, J. (1955). The construction of reality in the child, Routledge and Kegan Paul.

Pursula, M. (1999). "Simulation of traffic systems-An overview." J. Geographic Inf. Decision Anal., 3(1), 1-8.

Resnick, M. (1997). Turtles, termites, and traffic jams: Explorations in massively parallel microworlds, The MIT Press, Cambridge, Mass.

Romme, G. L. (2002). Microworlds for management education and learning, Tilburg Univ., Tilburg, The Netherlands.

Senge, P. M. (1990). The fifth discipline: The art and practice of the learning organization, Doubleday Currency, New York.

Svnicki, M. D., and Dixon, N. M. (1987). "The Kolb model modified for classroom activities." College Teaching, 35(4), 141-146.

Yerra, B., and Levinson, D. (2005). The emergence of hierarchy in transportation networks, Annals of Regional Sci., in press. 